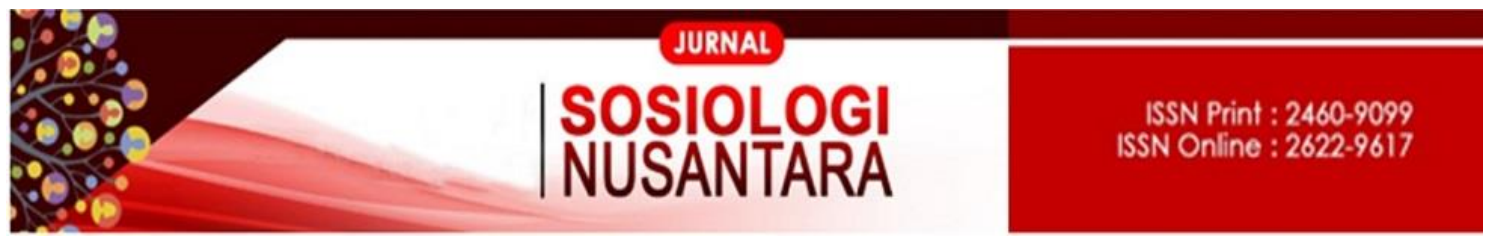

https://ejournal.unib.ac.id/index.php/jsn

DOI ://doi.org/10.33369/jsn.4.2.64-75

\title{
MAKNA SIMBOLIK TARI KEJEI SUKU REJANG
}

\section{THE SYMBOLIC MEANING OF KEJEI DANCE FROM REJANG TRIBE}

\author{
Gennes Arlin Mela C. Apindis', Sri Handayani Hanum², Sri Hartati² \\ srihartati.unib112@gmail.com
}

123. Fakultas Ilmu Sosial dan Ilmu Politik, Universitas Bengkulu

\begin{abstract}
Abstrak
Tari Kejeimerupakan salah satu tarian sakral yang berasal dari Suku Rejang. Penelitian ini bertujuan untuk mengetahui makna simbolik yang terkandung dalam setiap rangkaian Tari Kejei. Penelitian ini menggunakan metode penelitian deskriftip kualitatif dengan menggunakan Teori Interaksionisme Simbolik. Pengumpulan data dalam penelitian ini menggunakan teknik wawancara, observasi dan dokumentasi. Selanjutnya analisis data menggunakan reduksi data, analisis data dan penarikan kesimpulan. Kejeiadalah tarian yang memiliki makna rasa syukur kepada sang pencipta dan kepada sang leluhur karena telah diberikan rezeki yang melimpah, bisa hidup rukun berdampingan antar sesama masyarakat. Tarian ini juga sekaligus sebagai ajang pertemuan bujang dan gadis masyarakat Rejang untuk bermain bersama dan sebagai sarana untuk mencari jodoh. Tari Kejeidimulai dengan ritual Temu'un gongyaitu ritual sebelum penggunaan alat musik pengiring. Kemudian Jampi limauuntuk keselamatan para penari yang disebut juga anak sangei. Selanjutnya yaitu tari penyambutan, tarian ini untuk menyambut tamu yang hadir dan mempersilahkan duduk ditempat yang telah disediakan. Setelah tari penyambutan, lalu inti dari Tari Kejei yang terdiri dari 6 gerakan. Pertama, gerak sembah menari yang bermakna sebagai penghormatan kepada roh leluhur, kepada tamu agung dan kepada para penonton yang hadir pada saat acara Kejeiberlangsung. Kedua, gerak bederap salah pinggang yaitu gerak yang bermakna sebagai kebijaksanaan dalam mengambil keputusan. Ketiga, gerak metik jari sebagai bentuk penerimaanterhadap keluarga atau teman baru. Keempat, gerak mateak dayung sebagai makna penyerahan hidup kepada yang Maha Esa. Kelima, gerak sembah penyudo sebagai makna ucapan terimakasih atas kelancaran dalam melaksankan Tari Kejei. Keenam, gerakan yang terakhir yaitu gerak mendayung sebagai makna perpisahan. Baik perpisahan kepada leluhur, kepada penonton, kepada sesama penari. Tari Kejei tak luput dari unsur-unsur yang mendukung diantaranya penari, pemusik, sesaji sebagai simbol kemakmuran, kostum dan Tuwei batin(pawang).
\end{abstract}

Kata Kunci: Makna Simbol, Tari Kejei. 


\begin{abstract}
Kejei dance is one of the sacred dances originating from the Rejang tribe. This study aims to find out the symbolic meaning contained in each Kejei Dance series. This study uses qualitative descriptive research method using Symbolic Interactionism Theory. Data collection in this study uses interview, observation and documentation techniques. Furthermore, data analysis uses data reduction, data analysis and conclusion drawing. Kejeiis a dance that has the meaning of gratitude to the creator and to the ancestors because it has been given abundant sustenance, can live in harmony side by side between fellow communities. This dance is also at the same time as a meeting place for single and Rejang community girls to play together and as a means to find a mate. Kejei dance begins with the ritual of Temu'un gong, a ritual before the use of accompaniment musical instruments. Then the Jampi limau for the safety of the dancers called anak sangei. Next is the welcoming dance, this dance is to welcome guests who are present and invite to sit at the place provided. After the welcoming dance, then the core of the Kejei Dance consists of 6 movements. First, the dancing movements are meaningful as a tribute to the spirits of the ancestors, to the great guests and to the spectators present at the Kejei program. Secondly, the wrong movement of the waist is a meaningful movement as a policy in making decisions. Third, the movement of metic fingers as a form of acceptance of family or new friends. Fourth, the movement of mateak rowing as the meaning of surrender life to the Almighty. Fifth, the gesture of abstraction as a means of gratitude for the smooth running of Kejei Dance. Sixth, the last movement is rowing as a meaning of separation. Good separation from the ancestors, to the audience, to fellow dancers. Kejei dance does not escape the supporting elements including dancers, musicians, offerings as symbols of prosperity, costumes and Tuwei batin (pawang).
\end{abstract}

Keywords: Meaning of Symbol, Kejei Dance.

\title{
PENDAHULUAN
}

Indonesia yang didiami oleh banyak suku bangsa dari berbagai daerah mempunyai kesenian masing masing yang biasa disebut dengan kesenian tradisional. Kesenian ini ditampilkan pada saat acara-acara tertentu seperti pada musim panen, upacara perkawinan, atau upacara yang ada kaitannya dengan upacara keagamaan. Kesenian tradisional daerah merupakan karya seni yang bisa dimasukkan sebagai kebudayaan nasional seperti seni tari, seni suara, seni batik, seni sastra, seni drama dan sebagainya (Amri, 2009:3).

Salah satu provinsi yang ada di Indonesia, Bengkulu pun memiliki beraneka ragam adat istiadat baik itu dari suku, bahasa, ras dan budaya. Salah satunya yaitu Suku Rejang. Suku Rejang adalah suku tertua yang ada di Sumatera. Suku Rejang mendominasi wilayah Kabupaten Rejang Lebong (Curup), Kabupaten Bengkulu Tengah, Kabupaten Bengkulu Utara, Kepahiang dan Kabupaten Lebong. Suku Rejang memiliki Empat Mergo atau yang disebut dengan Rejang Pat Petulai atau Rejang Empat 
Petulai yaitu Mergo Bermani atau Bermano, Mergo Bejinggo, Mergo Sepanjang Jiwo, Mergo Bembo. Seperti hal nya suku-suku lain yang ada di Indonesia, Suku yang ada di Bengkulu memilikiberbagai macam kesenian seperti tari-tarian. Bengkulu memiliki lima tari tradisional daerah diantaranya Tari Andun, Tari Ganau, Tari Persembahan, Tari Lalan Belekdan salah satunya yang berasal dari Suku Rejang yaitu Tari Kejei. Tari Kejei merupakan tarian sakral yang diyakini masyarakat yang mengandung nilai dan makna tersendiri bagi masyarakat Rejang. Kejei pertama kali dilaksanakan adalah Kejei pernikahan Putri Senggang dan Biku Bermano. Tari Kejei dipercaya sudah ada sebelum kedatangan para Biku dari Majapahit. Sejak para Biku datang, alat musiknya diganti dengan alat dari logam, seperti yang digunakan sampai saat ini. Tari Kejei ditarikan oleh Anak Sangei atau yang disebut muda-mudi masyarakat Rejang. Kekhasan tari ini adalah alat-alat musik pengiringnya terbuat dari bambu, seperti kulintang, seruling dan gong. Namun sekarang alat musik tersebut terbuat dari kuningan. Tarian dimainkan sekelompok orang yang membentuk lingkaran dengan berhadap-hadapan searah menyerupai jarum jam.

Tari Kejei dilaksanakan tidak lagi serumit dan tidak dalam jenjang waktu yang lama, meskipun persyaratan tetap harus dijalankan namun pelaksanaannya yang sekarang lebih mudah dan lebih singkat. Hal ini dapat dibandingkan bahwa dahulu tuan rumah yang melaksanakan Tari Kejei harus benar-benar orang yang kaya, karena Kejeizaman dahulu membutuhkan biaya yang tidak sedikit, mulai dari pemotongan hewan berkaki empat, acara dilaksanakan minimal tiga hari tiga malam sehingga membutuhkan biaya konsumsi yang lebih banyak, tuan rumah juga harus berasal dari Suku Rejang asli dan setiap pasang penari juga diharuskan untuk tidak dalam satu marga yang sama. Namun sekarang Tari Kejei dilaksanakan cukup satu hari, dan tuan rumah yang berhajat tidak harus berasal dari masyarakat suku Rejang asli, untuk penari juga tidak harus berasal dari marga yang berbeda, siapapun bisa terlibat dalam melaksanakan Tari Kejei walaupun tak berasal dari masyarakat Rejang asli, asalkan muda mudi tersebut mampu menarikan Tari Kejei.Penari juga tidak harus berpuasa sebelum melaksanakan Tari Kejei, namun sampai saat ini tetap masih berkembang mengenai mitosnya bahwa tarian yang dilakukan oleh muda-mudi ini dikhususkan untuk penari perempuan yang masih perawan dan laki-laki harus masih perjaka. Dalam acara pernikahan Tari Kejeitidak hanya dilakukan oleh penarinya saja tetapi kedua 
mempelai harus ikut serta menari dengan penari penari lain. Hal ini melambangkan bahwa kedua mempelai akan segera melepas masa lajang mereka dan akan segera bertemu di pelaminan dan sebagai ajang perpisahan kepada teman teman lain yang masih lajang dan dilengkapi dengan adanya sesajen yang disebut dengan Penei.

Tari Kejei ini masih aktif dilaksanakan sampai saat ini, bahkan pada tahun 2017 Tari Kejeiditetapkan oleh Menteri Pendidikan dan Kebudayaan sebagai warisan budaya tak benda. Banyak sanggar-sanggar tari yang masih tetap eksis mempertahankan Tari Kejeimisalnya saja Sanggar Depun Keme yang terdapat di Kelurahan Durian Depun Kecamatan Merigi Kabupaten Kepahiang. Sanggar yang dibina langsung oleh Ibu SH salah satumantan Lurah Durian Depun didirikan pada tahun 2012 dan eksistensinya semakin hari semakin baik. Sanggar Depun Keme bisa menampilkan tarian dari 2 hingga 3 kali tampil dalam seminggu, hal ini tergantung panggilan dari orang-orang yang ingin menggunakan jasa sanggar dan tawaran tidak hanya di Kelurahan Durian Depun saja melainkan tempat lain sesuai dengan dimana sanggar ini dipanggil untuk menampilkan sebuah pertunjukan.

Menurut SH selaku pembina sanggar menyatakan bahwa setiap kali tampil untuk sebuah pertunjukan Tari Kejei, pihak mereka tetap memenuhi syarat yang harus dilakukan, seperti menyiapkan sesaji atau yang disebut dengan Penei. Sulasutra selaku ketua Badan Musyawarah Adat Kelurahan Durian Depun menyatakan bahwa Kelurahan Durian Depun merupakan salah satu kelurahan yang masih sering melaksanakan Tari Kejei baik dalam acara pernikahan maupun acara khitanan. Sekarang Tari Kejeitidak lagi serumit dahulu yang harus diadakan minimal 3 hari 3 malam, harus memotong hewan berkaki empat, persyaratan yang wajib dipenuhi tetap menjadi prioritas dan harus tetap dijalankan. Sanggar yang ada di Kelurahan Durian Depun menjadi jembatan untuk tetap mempertahankan tradisi dan budaya warisan leluhur masyarakat Suku Rejang.

Penelitian ini terfokus pada makna simbolik yang terkandung pada rangkaian Tari Kejei Suku Rejang. Tujuan penelitian ini yaitu untuk mengungkap fakta sosial mengenai makna simbolik yang terkandung pada rangkaian Tari Kejei Suku Rejang. Penelitian ini menggunakan teori interaksionisme simbolik. 


\section{METODE PENELITIAN}

Penelitian ini menggunakan metode penelitian kualitatif yang bersifat deskriptif dan dilakukan di Kelurahan Durian Depun Kecamatan Merigi Kabupaten Kepahiang karena Kelurahan Durian Depun merupakan salah satu kelurahan yang masih sering menampilkan Tari Kejei pada saat acara pernikahan maupun acara lainnya. Selain itu, di kelurahan ini terdapat sanggar tari yang masih sangat eksis terhadap Tari Kejei dan bukan hanya tampil di Kelurahan Durian Depun saja melainkan di desa lain bahkan di luar Kabupaten Kepahiang.

Data dan informasi yang dikumpulkan dari sejumlah informan yang dipilih dengan menggunakan teknik purposive sampling. Subyek yang dipilih sebagai informasi adalah orang yang terlibat dalam seni Tari Kejei. Teknik pengumpulan data yang dilakukan adalah dengan observasi (pengamatan), wawancara, serta dokumentasi. Teknik analisa data deskriptif kualitatif menggunakan tiga teknik yaitu reduksi data, penyajian data dan pengambilan kesimpulan.

\section{PEMBAHASAN}

\section{Makna Simbol dari rangkaian pelaksanaan Tari Kejei}

\section{Ritual Temu'un gong}

Ritual ini bermakna permohonan izin kepada leluhur agar pelaksanaan Tari Kejei bisa berjalan dengan baik tanpa adanya suatu halangan ataupun rintangan yang dapat menghambat proses Tari Kejei. Masyarakat Rejang mempercayai bahwa leluhur mereka yang sudah meninggal membantu mereka dalam menjaga keamanan desa. Bacaan dalam ritual temu'un gong dibacakan 3x oleh tuwei batin. Kemudian alat musik diasapi oleh asap kemenyan tersebut. Stabiek magea kumu (mohon pamit pada kamu/leluhur) sebagai ucapan minta izin diucapkan sebanyak 3 kali dan alat musik siap untuk diasapi oleh kemenyan yang dibakar tadi.

2. Jampi Limau Anak Sangei

Ritual ini sebagai simbol kekuatan yang bermakna agar para penari terhindar dari gangguan roh jahat atau kemasukan arwah para leluhur. Ritual Jampi limau adalah pemberian jampi limau dan tepung setawar oleh tuwei batin kepada anak sangei atau para penari dengan cara memercikkan daun sedingin dan setawar yang sudah direndam oleh air. Namun seiring berkembangnya ilmu agama dimasyarakat ritual jampi limau 
anak sangei tidak lagi dilaksanakan. Menurut bapak SS jampi limau tidak lagi dilaksanakan karena tuwei batinpada saat ini telah yakin kepada para penari bahwa didalam diri penari pada saat ini telah tertanam jiwa keyakinan dan keimanan untuk menjaga diri sendiri dari gangguan arwah leluhur dalam melaksanakan Tari Kejei tersebut.

3. Tari Penyambutan

Rangkaian selanjutnya yaitu tari penyambutan, yaitu menyambut orang yang dianggap agung yang nantinya penyambutan ini bertujuan untuk mengantarkan tamu duduk ditempat yang telah disediakan pada saat hari perayaan Kejei berlangsung. Tari penyambutan di tarikan oleh 5 orang perempuan atau lebih yang penting berjumlah ganjil, 4 orang membawa bokor yang berisi beras kunyit, dan satu orang yang posisinya paling depan pembawa bokor berisi rempah-rempah seperti pinang, tembakau, kapur sirih, sirih, Kemudian bokoryang dibawakan diberikan kepada tamu agung. Di dalam bokor yang terdapat rempah rempah yang sudah dipotong kecil-kecil dan halus ini merupakan simbol kemakmuran yang bermakna bahwa masyarakat Rejang memiliki kekayaan alam melimpah untuk digunakan dalam kehidupan sehari-hari dan rempahrempah tersebut tentu akan menjadi hidangan bagi setiap tamu yang datang.

\section{Inti Gerak Tari Kejei}

Rangkaian selanjutnya yaitu inti dari Tari Kejei, babak dimulai dari berdirinya para penari membentuk dua baris berbanjar, satu baris laki-laki dan satu baris perempuan. Posisi antara laki-laki dan perempuan tersebut merupakan simbol perbedaan dan batasan antara laki-laki dan perempuan yang belum menikah. Masyarakat Rejang percaya bahwa anak perempuan adalah aset yang harus dijaga sebelum menikah dan tidak boleh terlalu akrab dan bercampur baur dengan lawan jenis. Kemudian seorang perempuan yang bertugas untuk menyambei atau bersyair sebelum dan sesudah tarian Kejei dilaksanakan. Setelah gong berbunyi, tanda para penari mulai masuk arena menari dan langsung duduk diantara meja penei atau sesaji yang telah disiapkan dan seorang perempuan yang bertugas untuk menyambei tadi duduk di tengah atau di antara para penari perempuan dan laki-laki di depan meja penei. Di hadapan perempuan yang menyambei terdapat dupa, kemeyan, dan lampu kaleng sebagai simbol penawar yang bermakna bahwa dupa, kemenyan, dan lampu tersebut sebagai penawar dari gangguan roh jahat pada saat perempuan yang menyambei sedang menyampaikan syair sambei 
tersebut. Perempuan yang menyambei menutup wajah dengan kipas sebagai simbol rasa malu. Dahulu para penari Tari Kejei merupakan bujang gadis yang awalnya tidak saling mengenal, mereka bertemu ketika ada acara Kejei. Gadis Rejang harus memiliki rasa malu kepada orang yang baru dikenal, rasa malu tesebut menunjukkan jati diri seorang perempuan yang mempunyai harga diri dan kehormatan seorang perempuan. Sebelum melakukan gerakan yang pertama, seorang perempuan mulai menyambei sedangkan para penari duduk dan posisi kepala menunduk sebagai simbol penyerahan dan kepasrahan diri kepada sang pencipta yang bermakna bahwa setiap kegiatan atau acara harus dimulai dengan do'a atau ucapan pamit baik kepada sang pencipta maupun kepada para leluhur yang menjadi kepercayaan agar acara bisa berjalan dengan lancar dan semua yang terjadi diserahkan kepada sang pencipta.

\section{a. Gerak Sembah Menari}

Gerak sembah yang dilakukan sebanyak tiga kali, pertama makna sembah dilakukan untuk penghormatan kepada para leluhur. Kedua, sembah dilakukan untuk menyambut kedatangan tamu agung dan pada para penonton yang hadir dan penghormatan kepada sesama parapenari. Sembah ketiga bermakna penghormatan kepada sesama penari laki-laki dan perempuan, penghormatan ini semacam bentuk perkenalan antar sesama penari agar bisa saling akrab dan diharapkan bisa sampai menyusul pasangan yang sedang menikah kepelaminan.

\section{b. Gerak Bederap Salah}

Pinggang Gerak bederap salah pinggang memiliki makna sebagai langkah kebaikan. Setiap manusia diharapkan menuju kebaikan dan mampu membawa diri untuk kehidupan yang lebih baik. Gerak bederap salah pinggang untuk laki laki dan perempuan tidak sama. Pertama untuk gerak laki-laki, berdiri pelan-pelan dari posisi duduk sembah, yang bermakna bahwa dalam mengambil keputusan laki-laki masyarakat Rejang tetap berhati-hati dan tidak gegabah. Kedua, gerak bederap salah pinggang untuk perempuan, berdiri pelan pelan dengan posisi tangan berada di belakang pinggang yang bermakna bahwa perempuan harus siap menerima keputusan yang diambil oleh para lelaki.

\section{c. Gerak Metik Jari}

Gerak ini bermakna bahwa baik laki-laki maupun perempuan harus saling bertukar fikiran meskipun pada dasarnya keputusan diambil oleh laki-laki. Dalam 
gerakan ini penari laki-laki dan perempuan berjalan mengelilingi penei yang bermakna bahwa mereka telah sama-sama diterima dalam memperkenalkan diri, sudah diterima menjadi teman baru.

d. Gerak Mateak Dayung

Gerak mateak dayung adalah gerak yang dilakukan di tengah tengah para penari sedang berjalan mengelilingi penei atau sesaji, Untuk perempuan mengubah posisi tangan lurus ke bawah dan semua ujung jari menghadap kebelakang sambil memegang selendang sedangkan untuk laki laki mengubah posisi tangan lurus kesamping. Gerakan ini bermakna bahwa semua kehidupan yang terjadi diserahkan kepada sang pencipta, manusia hanya bisa berusaha dan selebihnya diatur oleh yang maha kuasa. Sedangkan dalam acara pernikahan gerakan mateak dayung bermakna sebagai simbol baik laki-laki dan perempuan ketika sudah ditakdirkan bersama mereka akan menerima dengan baik keadaan pasangan.

e. Gerak Sembah Penyudo

Gerak sembah penyudo sama dengan sembah yang pertama tadi, hanya saja dalam gerak sembah penyudo makna simbol yang terkandung didalamnya berisi sembah pamit kepada nenek moyang, tamu agung dan para penonton bahwa para penari telah melaksanakan tarian dan akan segera mengakhiri tarian tersebut.

\section{f. Gerak Mendayung}

Gerak mendayung adalah gerakan yang menandakan berakhirnya tarian Kejei.Sebagai simbol perpisahan. Perpisahan kepada para penari dan penonton. Gerakan ini berjalan ditempat sebanyak delapan hitungan dimulai dengan kaki kanan, Posisi badan tegak lurus, pandangan menghadap kedepan kemudian perlahan melangkah mundur membentuk satu barisan. Jika Kejeidiacara pernikahan, salah satu penari lakilaki dan satu perempuan menggandeng kedua mempelai menuju pelaminan. Hal ini bermakna simbol perpisahan bahwa teman-teman dari kedua mempelai sudah rela melepaskan masa lajang sahabatnya.

\section{Unsur-unsur Tari Kejei}

1. Tuwei batin

Tuwei batin dalam pertunjukkan Tari Kejei biasanya adalah tokoh yang dituakan pada saat acara bekejei. Tuwei batin dalam setiap pertunjukkan berganti-ganti atau berbeda-beda sesuai dengan tempat dimana acara berlangsung. 


\section{Penari}

Penari dalam tarian Kejei berjumlah ganjil misalnya 3 pasang, 5 pasang, 7 pasang dan seterusnya. Penari harus ganjil karena masyarakat Rejang mempercayai jumlah ganjil akan digenapi oleh arwah nenek moyang atau para leluhur. Penari harus masih dalam keadaan suci, seorang penari perempuan harus masih dalam keadaan perawan sedangkan penari laki-laki harus masih perjaka, hal ini sebagai simbol penyucian diri. Jika manusia selalu menjaga kesucian maka ia akan mendapat kesucian pula baik di dunia maupun di akhirat.

3. Pemusik

Dalam Tari Kejeipemusik atau penabuh iringan menjadi unsur yang juga sangat penting. Tanpa musik tarian seperti sayur tanpa garam. Dalam Tari Kejei musik yang dimainkan ada tiga macam alat musik yaitu kulintang, gong, redap, dan suling yang hanya digunakan pada saat tari penyambutan saja. Irama ombak laut merupakan simbol irama yang dimainkan naik turun yaitu kadang dibunyikan dengan keras kadang dibunyikan dengan pelan mengikuti gerakan tarian. Hal ini bermakna bahwa masyarakat Rejang harus memahami kondisi lingkungan yang ada dan dalam meakukan sesuatu tidak boleh setengah setengah. Ketika memang harus berjuang harus diselesaikan dengan baik apapun hasilnya.

4. Sesaji

Sesaji merupakan unsur penting dalam setiap ritual adat. Sesaji adalah sejenis persembahan kepada nenek moyang atau dewa pada upacara adat dikalangan penganut suatu kepercayaan. Dalam pelaksanaan Tari Kejei ada beberapa sesaji yang memang perlu disiapkan. Menurut bapak SS dalam pelaksanaan Tari Kejei, sesaji diletakkan dalam penei, penei adalah tempat meletakkan sesaji. Sesaji terdiri dari pisang emas setandan sebagai makna persatuan, sirih setangkai sebagai makna penerimaan tamu, daun setawar sedingin sebagai makna tanggung jawab terhadap perbuatan, buah kundur sebagai makna keindahan, tebu sebagai makna saling menjaga, selendang sebagai makna kasih sayang, payung agung sebagai bentuk kepercayaan bahwa adanya tuhan yang melindungi, minyak kelapa sebagai penawar malapetaka, lampu damar sebagai simbol penerangan, senapan dan tombak sebagai simbol kecerdasan, beronang sebagai makna kemampuan memilih hal baik dan buruk, kelapa dan jagung makna persaudaraan, beringin bermakna kekokohan. 


\section{Kostum}

Kostum merupakan segala sandang dan perlengkapan yang dikenakan penari diatas panggung. Tari Kejei merupakan tarian yang berpasang-pasangan antara laki-laki dan perempuan sehingga kostum yang dikenakan tentu berbeda. Menurut SH kostum laki-laki berupa baju jas warna hitam, celana hitam, selempang, cek ulew, kain songket.

\section{Analisis Makna Tari Kejei Berdasarkan Teori Interaksionisme Simbolik}

Teori yang digunakan dalam penelitian ini adalah interaksionalisme simbolik. Blumer menyimpulkan bahwa interaksionalisme simbolik adalah kehidupan yang bermasyarakat terbentuk melalui proses interaksi dan komunikasi antar individu antar kelompok dengan menggunakan simbol-simbol yang dipahami maknanya melalui proses belajar. Mead juga menjelaskan bahwa manusia hidup dalam lingkungan yang dipenuhi oleh simbol-simbol. Sama halnya dengan Tari Kejei, bahwa di dalam Tari Kejei terdapat simbol-simbol yang memiliki makna tersendiri bagi masyarakat Rejang. Masyarakat memaknai setiap rangkaian dan gerak Tari Kejei sebagai bentuk komunikasi. Komunikasi antar penari, komunikasi antar penari dan penikmat tari dan komunikasi kepada leluhur yang dipercayai.

Manusia pada hakikatnya adalah makhluk yang berinteraksi yang tidak hanya melulu berinteraksi secara ekslusif antar manusia tetapi juga inklusif dengan seluruh mikrokosmos. Terkadang manusia seperti halnya masyarakat Rejang dalam interaksi sosialnya melalui Tari Kejei disadari atau tidak menampakkan fenomenayang berupa simbol-simbol dan mempunyai banyak pemaknaan dalam simbol-simbol tersebut, hal inimerupakan refleksi dari fenomena interaksionisme simbolik.

\section{KESIMPULAN}

Hasil penelitian menunjukkan bahwa kejei adalah tarian yang memiliki makna rasa syukur kepada sang pencipta dan kepada sang leluhur karena telah diberikan rezeki yang melimpah, makmur dan bisa hidup dengan rukun berdampingan walaupun berbeda marga serta tarian ini juga sekaligus sebagai ajang pertemuan bujang dan gadis masyarakat Rejang untuk bermain bersama dan bahkan ada juga untuk mencari jodoh. Seiring berkembangnya zaman, Kejei dilaksanakan dalam acara pernikahan maupun khitanan. Hal ini disebabkan dalam acara pernikahan Tari Kejei dilaksanakan karena 
masyarakat percaya dengan melaksanakan pesta pernikahan menggunakan Kejei adalah bentuk rasa syukur karena telah memberi rezeki, jodoh sehingga bisa melaksanakan pernikahan dan dengan adanya Tari Kejei teman-teman dari pengantin diharapkan bisa menyusul temannya yang menikah karena adanya pertemuan bujang gadis melalui Tari Kejei tersebut. Selain itu Kejei pada saat acara pernikahan merupakan bentuk perpisahan kepada para pengantin karena telah melepas masa lajang. Oleh karena itu untuk Kejei dalam acara pernikahan, pengantin diikut sertakan menari Kejei.

Saran yang diberikan berdasarkan hasil penelitian yaitu pemerintah daerah bersama warga masyarakat diharapkan terus melestarikan budaya yang ada, seperti Tari Kejei yang ada di sanggar Depun Keme yang telah diteliti. Hal ini bisa dilakukan dengan cara menghadiri atau menampilkan Tari Kejei disetiap acara-acara di pemerintahan. Selain itu pemerintah juga bisa melakukan sosialisasi atau pelatihan kepada pembina sanggar dan para penari mengenai Tari Kejei. Semoga penelitian ini bisa menjadi bacaan yang bermanfaat dan bisa dipraktekkan dalam kehidupan seharihari.

\section{DAFTAR PUSTAKA}

Alila dan Maylanny. 2014. "Makna Simbol Emotikon dalam Komunitas Kaskus". Jurnal Sosioteknologi 13(2): 119-133.

Amri, Ulli. 2009. Eksistensi Kesenian Kuda Kepang Pada Masyarakat Etnis Jawa di Minangkabau. Skripsi. Padang: Universitas Andalas.

Bungin, Burhan. 2011. Penelitian Kualitatif. Jakarta: Kencana.

Edy, Sedyawati. 2012. Budaya Indonesia Kajian Arkeologi, Seni, dan Sejarah. Jakarta: Rajawali Perss.

Erin, Kartika. 2014. Fungsi Tari Kejei Pada Upacara Perkawinan di Curup Kabupaten Rejang Lebong. Skripsi. Yogyakarta: Universitas Negeri Yogyakarta.

Jazuli, M. 2014. Telaah Teoretis Seni Tari. Semarang: IKIP Semarang Press.

Kamus Besar Bahasa Indonesia. 2008. Jakarta: Gramedia Pustaka Utama.

Koentjaraningrat, 2009. Pengantar Ilmu Antropologi. Jakarta: Rineka Cipta. 
Kuswarsantyo. 2012. Pelajaran Tari: Image dan Kontribusinya terhadap Pembentukan Karakter Anak. Jurnal Seni Tari 3(1): 17-23.

Inge, Metasya. 2013. Tari Kejei Pada Masyarakat Suku Rejang. Skripsi. Yogyakarta: Universitas Pendidikan Indonesia.

Narwoko, Dwi Suyanto. 2007. Sosiologi Teks Pengantar dan Terapan. Jakarta: Kencana.

Ritzer, George. 1985. Sosiologi Ilmu Berparadigma Ganda. Jakarta: Rajawali.

Ritzer, George, Douglas J. Goodman. 2013. Teori Sosiologi Dari Teori Sosiologi Klasik sampai Perkembangan Mutakhir Teori Sosial Postmodern. Bantul: Kreasi Wacana.

Silalahi, Ulber. 2010. Metode Penelitian Sosial. Bandung: Rafika Aditama.

Sumandiyo, Hadi. 2005. Sosiologi Tari. Yogyakarta: Pustaka.

Sunarto, Kamanto. 2004. Pengantar Sosiologi. Jakarta: Universitas Indonesia. 